\title{
Distribution of Gypsiferous Soil Using Geoinformatics Techniques for Some Aridisols in Garmian, Kurdistan Region-Iraq
}

\author{
Salim Neimat Azeez \\ Survey Dept, \\ Darbandikhan Technical Institute , \\ Sulaimani Polytechnic University \\ salim.azeez@spu.edu.iq
}

\author{
Iraj Rahimi \\ Survey Dept. \\ Sulaimani Polytechnic University \\ iraj.amin@spu.edu.iq
}

\begin{abstract}
The paper deals with techniques of image classification developed to distinguish gypsiferous soils, using the integration of field observation and remote sensing and more specific Landsat/ETM imagery. A Landsat image was assembled and used in this study. The image was acquired by the ETM/Landsat 7 sensor, which was acquired on August, 2012.Two main data have been used in this research, I) Field and II) Satellite data. The amount of gypsum is different from location to other, may be due to the parent material of some locations of the study area which is rich with gypsum minerals, and there is evidence of Gypsic indopedon horizon. The results indicated that the amount of organic matter decreases with increasing the amount of gypsum. In general, the study area is rich with total lime. These results reflect the effect of decalcification and calcification processes caused the formation of illuvial subsurface (calcic) horizon in some location of the study area.

The $\mathrm{pH}$ values were around neutral to slightly alkaline due to the effect of calcareous parent material and type of climatic conditions. The low ECe values indicate that the soil was non-saline reflected by low values of ECe. The soil classes of the study area are belonging to Haplogypsids, Haplocalcids, Haplocambids, Calciargids and Haplargids. Two maps were prepared to show the distribution of gypsiferous in the study area, the first one is map which shows the output of supervised classification and maximum- like hood for specific, and the second is the thermal-based classification. Thermal-based map could predict the gypsiferous area in a better way, than the classification based only on spectral properties of non-thermal bands.
\end{abstract}

Key word: Gypsiferous, Aridisols, Remote Sensing, Landsat/ETM imagery, indopedon horizon, Thermalbased map.

\section{INTRODUCTION}

The studies on the distribution of gypsum in Iraqi Kurdistan through a very rare technique were not exist, especially in Garmian Kurdistan region, where the gypsum is important components in several areas such as agriculture, engineering and industry. Where soils gypsum spread over large areas of the world's dry, arid and semi-private regions, including Iraq, where cover more than 1.2 million hectares and about $28.6 \%$ of the soil cover of Iraq [1], [2].

Gypsiferous soils represent serious problems in many fields of human activity. They have dramatic impacts on buildings and infrastructure. The gypsiferous soils consist of a secondary gypsum-rich crust within the soil, developed after sedimentation of the soil material by increasing evaporation of saline and sulphate-rich groundwater in arid and warm regions. In fact, gypsiferous soils retain most of the original soil components (clay, silt and sand) but, impregnated by variable amounts of gypsum; as nests or disseminations. Fine-grained soils contain more gypsum than coarse grained soils [3].

Many soil scientists and engineers have studied the gypsiferous soils in variable locations of the world and for different purposes, i.e. agriculture, surveying, civil engineering etc. Among those scientists and engineers, some have given different gypsiferous soils classification systems [4], [5], [6], [7], [8], [9], [10], [11], [12], [13]. Many researchers noticed that the coefficient of compressibility and the in-situ void ratio increase with increasing gypsum content. Also they found that wetting of gypsiferous soils contributes in increasing of compressibility due to gypsum removal and collapse. [14], [15], [11], [16], [17], [18], [19], [20].

Remote Sensing (RS) data and techniques have been widely used to observe the Earth and getting reliable information about the under, above and on the surface of the Earth. Soil science, like many other scientific fields has been using the privileges of RS for more than two decades and there are many remotely sensed models to detect mineral, solve soil challenges, and show different mineral distribution on the Earth's surface. In the field of detecting and mapping gypsum and gypsiferous area distribution, RS shall be used effectively as done in many studies. [21] produced thematic maps indicating gypsiferous, and clayey surface using Landsat/TM bands 3,4, and 5. They declared that TM is valuable aid for mapping soil in arid regions. [22] used 
decorrelation stretch methods applied on Landsat TM data to map halite, gypsum and their Chilean salt flat. [23] used Landsat TM imagery and spectral mixture analysis to show gypsum, halite, vegetation, and moisture in the Chott el Djerid salt playa, Tunisia. [24] carried a study to identify and decline gypsum

mined soils in parts of Coimbatore district, Tamil Nadu State, India using RS focusing on SPOT1 images. [25] used Thermal Infrared Multispectral Scanner (TIMS) to map playa evaporate minerals such as gypsum, and halite at Death Valley, California. The research is focusing on the following aims:

1. Distribution of gypsiferous soil using geoinformatics techniques.

2. Classification of gypsiferous soil.

\section{MATERIALS AND METHODS}

\section{1. Description of the study area}

Garmian is a widely region of Kurdistan, the study area is lies between latitude $34^{\circ} 36^{\prime} 49.3^{\prime \prime}$ in Teran Agha vilage to

$34^{\circ} 46^{\prime} 57.6^{\prime \prime} \mathrm{N}$ in Kany Maran and longitude $44^{\circ} 50^{\prime}$ $49.5^{\prime \prime}$ in Kngrean to $45^{\circ} 35^{\prime} 44.7^{\prime \prime} \mathrm{E}$ in Masjed village.

The elevation of study area ranged between 161.5 meters in Kngrean village and 487.1 meters in Kany Krmange village. The soil map units of the study area were obtained from the soil map units of Garmian, Iraqi Kurdistan region prepared by [26]. The data of latitudes, longitudes and elevations of soil sample locations were collected using a (GPS) receiver model GARMIN 72.

Geologically the study area lies within the foot hill physiographic unit for Iraq [27], as well as in the tectonic side, it is located in folds' zone [28]. Climate of the study area is continental semiarid by PE (Pontential Evaportrasiration) according to [29]. Soil moisture regime of the study area described as Torric [30]. While the soil temperature regime is hyperthermic [31]. The native vegetation including Cynodon dactylon, Ammi majus and Alhagi graeccorum [32]. The cultivation in the study area depends only on the rainfall.

\subsection{Field work}

Soil map units prepared by [26], reconnaissance soil survey map prepared by [33] and topographic map [34] were used as basic maps for this study. A total of 52 location of the study area were selected using a grid system method. The locations of points were georefrenced on the satellite image (August, 2012) after coordination of each point was selected. The coordination of each point on the ground was determined using GPS device. Samples of surface soil from a depth of $(0-30 \mathrm{~cm})$ were taken from each location (Figure 1). Samples were air-dried, grinded and passed through sieves of ( $2 \mathrm{~mm}$ ) opening diameters to determine gypsiferous soil. ArcGIS software package was used to map the gypsiferous soil units.

\subsection{Remotely sensed dataset}

\subsubsection{Remotely sensed}

This paper deals with techniques of image classification developed to distinguish gypsiferous soils, using the integration of field observation and remote sensing and more specific Landsat/ETM imagery. A landsat image was assembled and used in this study. The image was acquired by the Landsat 5 TM sensor, which was acquired on 3rd August, 2012.

\subsubsection{Dataset}

Two main data have been used in this research, I) Field and II) Satellite data. Field data include about 45 soil samples with a widespread distribution. The samples have been all tested in the library to see the presence of gypsum.

The satellite data used in this study is Landsat 7 Enhanced Thematic Mapper Plus (ETM+) Level-1G data which have eight bands sensitive to various wavelengths of Visible Infrared (VNIR), Short Wavelength Infrared (SWIR), and Thermal Infrared (TIR) [35]. Landsat 7 ETM+ Level-1G data were radiometrically and geometrically corrected to the same map projections, image orientations and spatial resolution. The image which is used in this study is taken in September which vegetation cover in the study area

is rare.

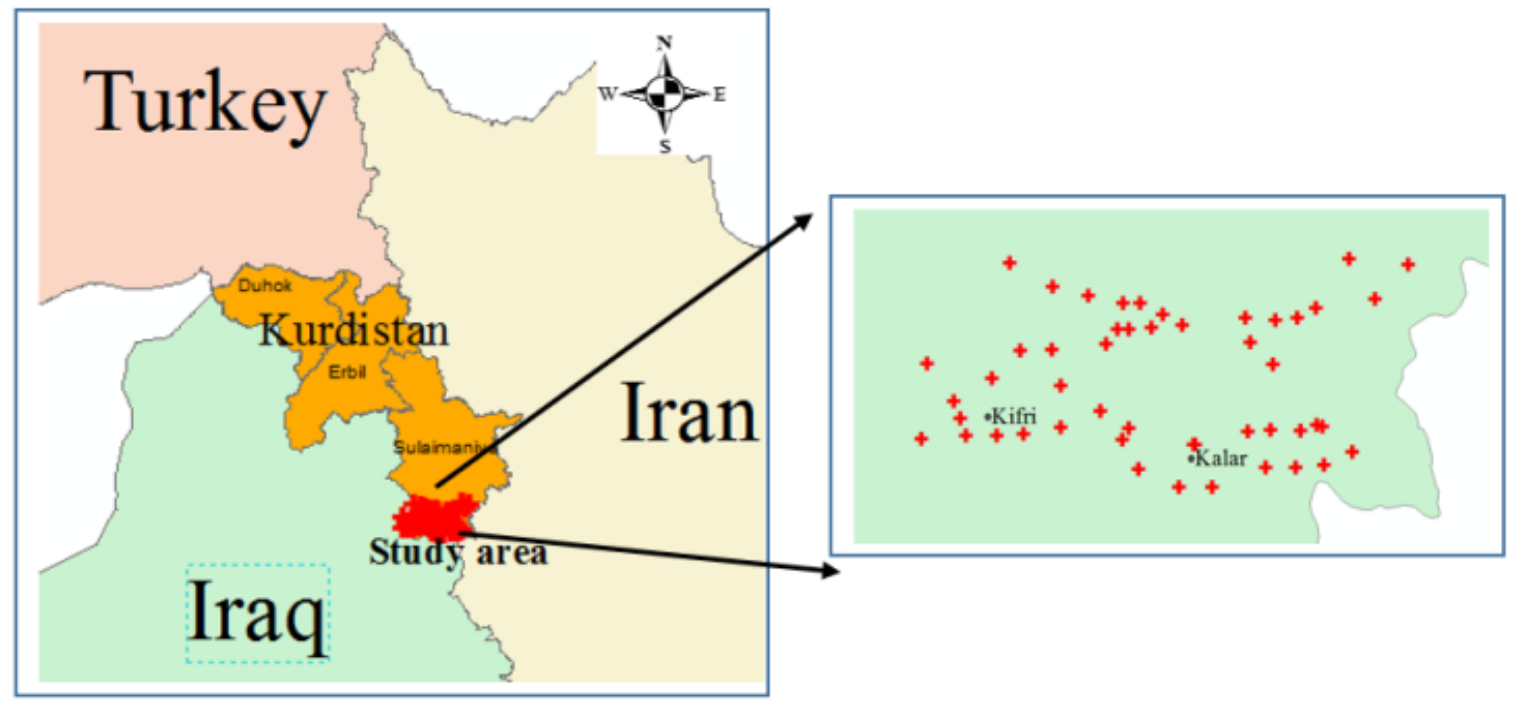

Figure 1: The study area (left) and the way sample points are distributed in the area ( right). 


\subsection{Processing}

\subsubsection{Laboratory analyses}

Soil samples were air dried and mixed to be homogenous, grinded using wood mortar, then passed through $2 \mathrm{~mm}$ sieve and kept in plastic containers for Gypsum. Gypsum was determined by shaking $5 \mathrm{gm}$ of soil sample with distilled water and then the gypsum was measured according to the acetone precipitated method [36], [37], [38].

\subsubsection{Satellite analysis}

Considering different suggested methods for different cases it's decided to use supervised classification. Two kind of classifications have been used resulting in two outputs which lets us to make a comparison different ways and different bands capability, besides assessing the ability of RS to map gypsum in the study area. Using Maximum-likehood classification, at the first place, tried to classify the image using three samples, as training control point, this had been analyzed precisely in laboratory. To get rid of noises, as well as, unnecessary data in the image the classification was proceed with applying Principle Component Analysis (PCA) function on the image [39]. The second scenario was, actually, using thermal band to classify the image knowing that gypsiferous areas show quite specific reflection behavior in thermal bands [40]. Thermal bandshelp thorough displaying Land Surface Temperature (LST). The temperature calibration of the thermal infrared band into the value of ground temperature has been done using the equations below (Eq. 1 and 2), [41].

$$
\begin{aligned}
& \mathrm{L}=\mathrm{Lmin}+((\mathrm{Lmax}-\mathrm{Lmin}) / 255) \times \mathrm{Q} \ldots \ldots . .[\text { Eq.1] } \\
& \mathrm{T}=\mathrm{K} 2 /(\ln (\mathrm{K} 1 / \mathrm{L}+1) \ldots \ldots . . \text { Eq.2] }
\end{aligned}
$$

Where L: Value of radiance in thermal infrared.

$\mathrm{T}$ : Ground temperature (K).

Q: digital record.

$\mathrm{K} 1, \mathrm{~K} 2$ : calibration coefficients.

Annual soil temperature (ta) can be predicated from the corresponding annual air temperature (Ta) according to the relationships suggested by the USDA soil taxonomy as:

$$
\text { ta }=\mathrm{Ta}+1^{\circ} \mathrm{C} \ldots \ldots . . \text { Eq.3] [41]. }
$$

Only three control points, among about 45 tested field points, have been used to train and classify the satellite image (table 1). The rests have been used to assess how accurate the developed maps could show the distribution of gypsum in the study area. It should be mentioned that the study area is mostly of no tree and very little vegetation cover at the date the image has been taken. Therefore, the thermal band mostly shows the soil surface.

\begin{tabular}{|c|c|c|c|}
\hline \multirow{2}{*}{ Points } & \multirow{2}{*}{ Latitude N } & \multirow{2}{*}{ Longitude E } & Gypsum \\
\cline { 3 - 4 } & & & $\mathbf{g ~ k g ~}^{\mathbf{1}}$ \\
\hline $\mathbf{1}$ & 514055 & 3831740 & 281.82 \\
\hline $\mathbf{2}$ & 502174 & 3843000 & 219.38 \\
\hline $\mathbf{3}$ & 494706 & 3848480 & 234.78 \\
\hline
\end{tabular}

Table 1: Points which are used to train the model.

\section{Results and Discussion \\ 3.1. Gypsum}

The results of (table 2) indicated that the amount of gypsum is different from location to other, the high amount was $533 \mathrm{~g} \mathrm{~kg}^{-1}$ soil in Serchem may be due to the parent material of some location of the study area which is rich with gypsum minerals, and evidence of Gypsic indopedon horizon is present [26]. While the lowest amount of gypsum was $0.98 \mathrm{~g} \mathrm{kg-1}$ soil recorded in Chala Rash due to parent material which is calcite materials from the soil slum [26].

\subsection{Organic matter (OM)}

It is clear from the (table 2) that the study area is poor with vegetation cover, where the highest amount which record was $22.46 \mathrm{~g} \mathrm{~kg}^{-1}$ soil in while the lowest amount was 8.02 in Pera Mony because of low rainfall ratio in the region. In general, the results indicate that the amount of organic matter decreases with increasing the amount of gypsum, and thus which mentioned by [43], where Gypsum affects the decomposition of organic matter as a result of increasing the concentration of calcium and sulfate in the soil solution in a way that affects the activity of organisms and its enzymes and there may be an effect of calcium carbonate for the packaging of organic matter [44]. Also the results agree with the results which obtained by [45], where confirmed that the calcium carbonate is a wrapper around organic matter, when he said that the solubility and re-deposition of gypsum may lead to the creation of gypsum covers around the organic material that protects the organic matter from attacking the organism. It is possible that there will be complexes of organic matter (especially polysaccharides) and dissolved calcium ion, which will increase in quantity in gypsum soils, leading to the increase of such complexities. These complexes inhibit the activity of organisms and their enzymes in the decomposition of organic matter [46].

Table 2: The soil sample locations names, their coordinates and some chemical properties. 


\begin{tabular}{|c|c|c|c|c|c|c|c|c|}
\hline \multirow{2}{*}{ No. } & \multirow{2}{*}{$\begin{array}{c}\text { Soil sample location } \\
\text { name }\end{array}$} & Latitude $\mathbf{N}$ & Longitude E & Gypsum & O.M.* & Total L.** & \multirow{2}{*}{$\frac{\mathrm{pH}}{\text { (extract) }}$} & \multirow{2}{*}{$\begin{array}{c}\mathrm{ECe} \\
(\mathrm{ds} / \mathbf{m}) \\
\end{array}$} \\
\hline & & \multicolumn{2}{|l|}{ (DMS) } & \multicolumn{3}{|c|}{ g kg-1 soil } & & \\
\hline 1 & Kangrean & $44^{\circ} 50^{\prime} 46.736^{\prime \prime}$ & $34^{\circ} 39^{\prime} 15.2^{\prime \prime}$ & 510.42 & 8.15 & 285 & 7.37 & 2.76 \\
\hline 2 & Karez & $44^{\circ} 55^{\prime} 24.775^{\prime \prime}$ & 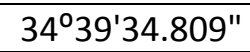 & 530.31 & 8.70 & 265 & 7.12 & 1.87 \\
\hline 3 & Serchem & $44^{\circ} 58^{\prime} 44.885^{\prime \prime}$ & 34여'ㄴ.889" & 533.71 & 9.34 & 250 & 7 & 0.98 \\
\hline 4 & Dwanza Emam & $45^{\circ} 1^{\prime} 36.41^{\prime \prime}$ & $34^{0} 39^{\prime} 43.474^{\prime \prime}$ & 484.11 & 11.22 & 245 & 7.1 & 0.87 \\
\hline 5 & Gakoli & $45^{\circ} 5^{\prime} 25.147^{\prime \prime}$ & $34^{\circ} 40^{\prime} 13.428^{\prime \prime}$ & 422.02 & 15.39 & 275 & 7.01 & 0.79 \\
\hline 6 & Die Bne & $45^{\circ} 13^{\prime} 35.808^{\prime \prime}$ & $34^{0} 36^{\prime} 40.197^{\prime \prime}$ & 100.36 & 20.76 & 255 & 7.38 & 1.02 \\
\hline 7 & Rezgary & $45^{\circ} 12^{\prime} 34.5^{\prime \prime}$ & $34^{\circ} 40^{\prime} 15.2^{\prime \prime}$ & 3.47 & 14.88 & 185 & 7.51 & 0.94 \\
\hline 8 & Qelai Sherwana & $45^{\circ} 17^{\prime} 25.274^{\prime \prime}$ & $34^{0} 35^{\prime} 11.094^{\prime \prime}$ & 3.35 & 15.33 & 255 & 7.66 & 0.81 \\
\hline 9 & Wali Aga & $45^{\circ} 21^{\prime} 9.612^{\prime \prime}$ & $34^{0} 35^{\prime} 10.503^{\prime \prime}$ & 2.71 & 13 & 245 & 7.64 & 0.77 \\
\hline 10 & Teran Aga & $45^{\circ} 26^{\prime} 42.584^{\prime \prime}$ & $34^{\circ} 37^{\prime} 6.234^{\prime \prime}$ & 3.05 & 10.38 & 250 & 7.51 & 0.99 \\
\hline 11 & Sobhana & $45^{\circ} 30^{\prime} 18.609^{\prime \prime}$ & $34^{0} 36^{\prime} 51.649^{\prime \prime}$ & 4.25 & 11.80 & 235 & 7.44 & 0.87 \\
\hline 12 & Seid Mostafa & $45^{\circ} 32^{\prime} 56.573^{\prime \prime}$ & $34^{\circ} 36^{\prime} 58.182^{\prime \prime}$ & 2.11 & 8.16 & 280 & 7.53 & 0.96 \\
\hline 13 & Kany Sheran & $45^{\circ} 35^{\prime} 50.623^{\prime \prime}$ & $34^{\circ} 38^{\prime} 8.064^{\prime \prime}$ & 3.27 & 8.23 & 260 & 7.41 & 0.89 \\
\hline 14 & Masjed & $45^{\circ} 35^{\prime} 45.801^{\prime \prime}$ & $34^{\circ} 54^{\prime} 41.009^{\prime \prime}$ & 4.49 & 8.11 & 280 & 7.56 & 1.04 \\
\hline 15 & Palgy Bchook & $44^{0} 54^{\prime} 11.499^{\prime \prime}$ & $34^{\circ} 42^{\prime} 31.836^{\prime \prime}$ & 493.96 & 8.19 & 285 & 7.47 & 3.22 \\
\hline 16 & Kifri & $44^{\circ} 54^{\prime} 54.102^{\prime \prime}$ & $34^{\circ} 41^{\prime} 3.608^{\prime \prime}$ & 528.39 & 11.92 & 280 & 7.45 & 2.61 \\
\hline 17 & Goban & $44^{\circ} 58^{\prime} 12.002^{\prime \prime}$ & $34^{\circ} 44^{\prime} 32.3^{\prime \prime}$ & 477.80 & 11.73 & 260 & 7.48 & 2.51 \\
\hline 18 & Weli Hayer & $45^{\circ} 5^{\prime} 24.202^{\prime \prime}$ & $34^{\circ} 43^{\prime} 52.3^{\prime \prime}$ & 96.00 & 10.52 & 215 & 7.49 & 1.08 \\
\hline 19 & Aola Qot & $45^{\circ} 9^{\prime} 34.504^{\prime \prime}$ & $34^{\circ} 41^{\prime} 39.473^{\prime \prime}$ & 41.14 & 12.31 & 195 & 7.40 & 0.96 \\
\hline 20 & Shakel & $45^{0} 11^{\prime} 53.999^{\prime \prime}$ & 34여'14.664" & 2.31 & 14.84 & 175 & 7.53 & 0.97 \\
\hline 21 & Kalar & $45^{0} 19 ' 39.106^{\prime \prime}$ & $34^{0} 38^{\prime} 57.522^{\prime \prime}$ & 4.12 & 20.81 & 285 & 7.65 & 1.07 \\
\hline 22 & Ban Zamen & $45^{\circ} 25^{\prime} 2.597^{\prime \prime}$ & $34^{\circ} 39^{\prime} 52.762^{\prime \prime}$ & 1.97 & 22.46 & 280 & 7.62 & 0.74 \\
\hline 23 & Sangary saroo & $45^{\circ} 27^{\prime} 22.401^{\prime \prime}$ & $34^{\circ} 40^{\prime} 1.037^{\prime \prime}$ & 2.07 & 19.47 & 240 & 7.65 & 0.63 \\
\hline 24 & Sangary Chwaroo & $45^{\circ} 30^{\prime} 31.303^{\prime \prime}$ & $34^{0} 39^{\prime} 59.165^{\prime \prime}$ & 2.19 & 19.53 & 255 & 7.69 & 0.65 \\
\hline 25 & Chwar Shakh & $45^{\circ} 1 ' 11.9^{\prime \prime}$ & $34^{\circ} 46^{\prime} 51.172^{\prime \prime}$ & 152.88 & 8.09 & 265 & 7.45 & 1.43 \\
\hline 26 & Kany Maran & $45^{\circ} 4^{\prime} 32.201^{\prime \prime}$ & $34^{\circ} 46^{\prime} 57.536^{\prime \prime}$ & 37.19 & 14.26 & 235 & 7.66 & 1.07 \\
\hline 27 & Mlesora & $45^{\circ} 10^{\prime} 11.903^{\prime \prime}$ & $34^{\circ} 47^{\prime} 27.909^{\prime \prime}$ & 12.63 & 18.57 & 220 & 7.61 & 0.88 \\
\hline 28 & Peaza Jar & $45^{\circ} 11 ' 22.101^{\prime \prime}$ & $34^{\circ} 48^{\prime} 41.236^{\prime \prime}$ & 4.80 & 18.59 & 215 & 7.64 & 0.82 \\
\hline 29 & Poqa & $45^{\circ} 12^{\prime} 36.601^{\prime \prime}$ & $34^{\circ} 48^{\prime} 41.945^{\prime \prime}$ & 3.72 & 18.08 & 205 & 7.60 & 0.95 \\
\hline 30 & Kany Chapllay Saroo & $45^{\circ} 14^{\prime} 58.501^{\prime \prime}$ & $34^{\circ} 48^{\prime} 49^{\prime \prime}$ & 2.91 & 17.17 & 180 & 7.60 & 1.02 \\
\hline 31 & Torka & $45^{\circ} 18^{\prime} 9.401^{\prime \prime}$ & $34^{\circ} 49^{\prime} 0.7^{\prime \prime}$ & 1.33 & 16.89 & 225 & 7.63 & 0.77 \\
\hline 32 & Zamawanga & $45^{\circ} 25^{\prime} 17.803^{\prime \prime}$ & $34^{\circ} 47^{\prime} 30.901^{\prime \prime}$ & 1.88 & 17.95 & 255 & 7.54 & 0.56 \\
\hline 33 & Chala Rash & $45^{\circ} 27^{\prime} 40.098^{\prime \prime}$ & $34^{\circ} 45^{\prime} 37.972^{\prime \prime}$ & 0.98 & 9.41 & 275 & 7.52 & 0.32 \\
\hline 34 & Kany Pamo & $45^{\circ} 32^{\prime} 51.797^{\prime \prime}$ & $34^{\circ} 40^{\prime} 18.409^{\prime \prime}$ & 1.92 & 11.63 & 250 & 7.82 & 0.28 \\
\hline 35 & Barda Soor & $45^{\circ} 32^{\prime} 15.497^{\prime \prime}$ & $34^{\circ} 40^{\prime} 26.135^{\prime \prime}$ & 3.55 & 19.05 & 255 & 7.81 & 0.74 \\
\hline 36 & Kany Krmange & $45^{\circ} 38^{\prime} 25.401^{\prime \prime}$ & $34^{\circ} 51^{\prime} 11.901^{\prime \prime}$ & 3.66 & 14.77 & 205 & 7.51 & 0.79 \\
\hline 37 & Zenanei Bchook & $44^{\circ} 51^{\prime} 24.103^{\prime \prime}$ & $34^{\circ} 45^{\prime} 44.436^{\prime \prime}$ & 209.40 & 8.16 & 280 & 7.43 & 3.16 \\
\hline 38 & Pera Mony & $45^{\circ} 0^{\prime} 7.199^{\prime \prime}$ & $34^{\circ} 54^{\prime} 23.209^{\prime \prime}$ & 243.30 & 8.02 & 240 & 7.52 & 1.64 \\
\hline 39 & Tapa Spi & $45^{\circ} 4^{\prime} 34.6^{\prime \prime}$ & $34^{\circ} 52^{\prime} 19.272^{\prime \prime}$ & 120.30 & 9.30 & 230 & 7.54 & 1.13 \\
\hline 40 & Zhalan & $45^{\circ} 8^{\prime} 20.404^{\prime \prime}$ & 345'ㄴ'33.201" & 31.80 & 13.70 & 200 & 7.64 & 0.76 \\
\hline 41 & Hawaralara & $45^{\circ} 11^{\prime} 58.003^{\prime \prime}$ & $34^{\circ} 50^{\prime} 58.001^{\prime \prime}$ & 22.90 & 15.93 & 255 & 7.63 & 0.65 \\
\hline 42 & Hawara Barza & $45^{\circ} 13^{\prime} 43.701^{\prime \prime}$ & $34^{\circ} 50^{\prime} 56.909^{\prime \prime}$ & 7.30 & 15.02 & 240 & 7.72 & 0.604 \\
\hline 43 & Garmic & $45^{0} 16^{\prime} 7.103^{\prime \prime}$ & $34^{\circ} 49^{\prime} 58.774^{\prime \prime}$ & 3.10 & 12.70 & 235 & 7.62 & 0.58 \\
\hline
\end{tabular}

Table 2: The soil sample locations names, their coordinates and some chemical properties (complement).

\begin{tabular}{|l|c|c|c|c|c|c|c|}
\hline No. & Soil sample & Latitude N & Longitude E & Gypsum & O.M.* & Total L.** & pH \\
\hline
\end{tabular} 


\begin{tabular}{|c|c|c|c|c|c|c|c|c|}
\hline & location name & ( D M S ) & & & g kg-1 & & (extract) & $(\mathrm{ds} / \mathrm{m})$ \\
\hline 44 & Soferahim & $45^{\circ} 41^{\prime} 55.701^{\prime \prime}$ & $34^{0} 54^{\prime} 6.601^{\prime \prime}$ & 2.60 & 11.31 & 235 & 7.64 & 0.55 \\
\hline 45 & Jolal Kawa & $45^{0} 24^{\prime} 48.701^{\prime \prime}$ & $34^{\circ} 49^{\prime} 39.937^{\prime \prime}$ & 1.70 & 11.83 & 230 & 7.63 & 0.57 \\
\hline 46 & Bawanor & $45^{0} 27^{\prime} 58.398^{\prime \prime}$ & $34^{\circ} 49^{\prime} 27.435^{\prime \prime}$ & 1.00 & 14.26 & 200 & 7.71 & 0.51 \\
\hline 47 & Ali Pacan & 45030'13.299" & $34^{\circ} 49^{\prime} 38.673^{\prime \prime}$ & 2.50 & 17.84 & 155 & 7.79 & 0.73 \\
\hline 48 & Shawaze & $45^{0} 32^{\prime} 14.703^{\prime \prime}$ & $34^{\circ} 50^{\prime} 26.239^{\prime \prime}$ & 3.42 & 14.83 & 205 & 7.54 & 0.81 \\
\hline 49 & Palgy Gaora & $44^{\circ} 56^{\prime} 20.875^{\prime \prime}$ & $34^{\circ} 46^{\prime} 43.167^{\prime \prime}$ & 234.75 & 8.80 & 280 & 7.44 & 2.56 \\
\hline 50 & Ebrahim khan & $45^{\circ} 1 ' 17.518^{\prime \prime}$ & $34^{\circ} 43^{\prime} 36.394^{\prime \prime}$ & 219.38 & 9.32 & 245 & 7.43 & 1.96 \\
\hline 51 & Sei Malale & $45^{\circ} 9^{\prime} 12.821^{\prime \prime}$ & $34^{\circ} 37^{\prime} 35.29^{\prime \prime}$ & 281.82 & 12.39 & 205 & 7.45 & 0.99 \\
\hline 52 & Nehrwan & $44^{\circ} 48^{\prime} 33.26^{\prime \prime}$ & $34^{\circ} 40^{\prime} 35.482^{\prime \prime}$ & 385.07 & 8.00 & 295 & 7.45 & 3.04 \\
\hline
\end{tabular}

$*=$ Organic Matter, $* *=$ Total Lime

\subsection{Total lime}

Table (2) show that the amount of total lime is ranged between $155 \mathrm{~g} \mathrm{~kg} \mathrm{-1}$ soil in Ali Pacan and $285 \mathrm{~g} \mathrm{~kg} \mathrm{-1} \mathrm{in}$ Kangrean and Masjed., in general the study area is rich with total lime because the parent material is calcareous. These results reflect the effect of decalcification and calcification processes caused the formation of illuvial subsurface (calcic) horizon in some location of the study area.

\subsection{Soil reaction $(\mathrm{pH})$}

The $\mathrm{pH}$ values in (table 2) were around neutral to slightly alkali due to the effect of calcareous parent material and

type of climatic conditions. The lowest $\mathrm{pH}$ value was 7 in Sercham, while the highest value was 7.82 in Kany Pamo.

\subsection{Electrical conductivity (ECe)}

The ECe values which shown in (table 2). indicate that the soil was non-saline reflected by low values of ECe. The low soluble salt contents in all location may be due to natural of parent material. In general, the values of ECe of study area ranged between $0.28 \mathrm{ds} / \mathrm{m}$ in Kany Pamo, while the highest values were $3.22 \mathrm{ds} / \mathrm{m}$ in Palgay Bchook.

Mentioned that the soil of the study area is belong to Haplogypsids, Haplocalcids, Haplocambids, Calciargids and Haplargids. [26].

\subsection{Mapping}

Classification, as per the methods applied, resulted into two maps (figures 2 and 3). The training points are shown in black triangles, while other field points, which are used as check points, are displayed in different shapes and colors. Figure (2) shows the map which shows the output

of supervised classification, maximum- likehood for specific. At the second place, (figure 3) is of the thermalbased classification. Both maps show probable gypsiferous areas in form of some discrete points which their density displays the attendance of gypsum in different places. According to the check points which cover a wide range of gypsum attendance, from about 2 $\mathrm{mg}$ to more than 500mg, thermal-based map (figure 3) could predict the gypsiferous area in a better way, than the classification based only on spectral properties of non-thermal bands (figure 2). This results agree with the results of [40] where they explore the possibilities of distinguishing saline from gypsiferous soils, using remote sensing data, especially the Landsat TM sensor. They used supervised image classification to differentiate gypsiferous from other soils as well. Their study offered thermal band of the Landsat TMsensor as the best way to differentiate between gypsiferous and saline soils. It was shown, furthermore, that TM thermal band is quite reliable for mapping soils containing gypsumin a relatively fast and accurate way.

In many areas both maps present gypsum distribution almost the same way, but for the areas of high gypsum attendance, thermal map act, considering field points, more accurate (figure 4). For instance, as seen in (figure 4), the overlap between points of high gypsum (green and blue triangles) and map's predicted gypsiferous area is higher in the left map, which is thermal-based map. While, in predicting the areas of low gypsum attendance the both map, almost, are doing the same way, as well as, satisfying. 


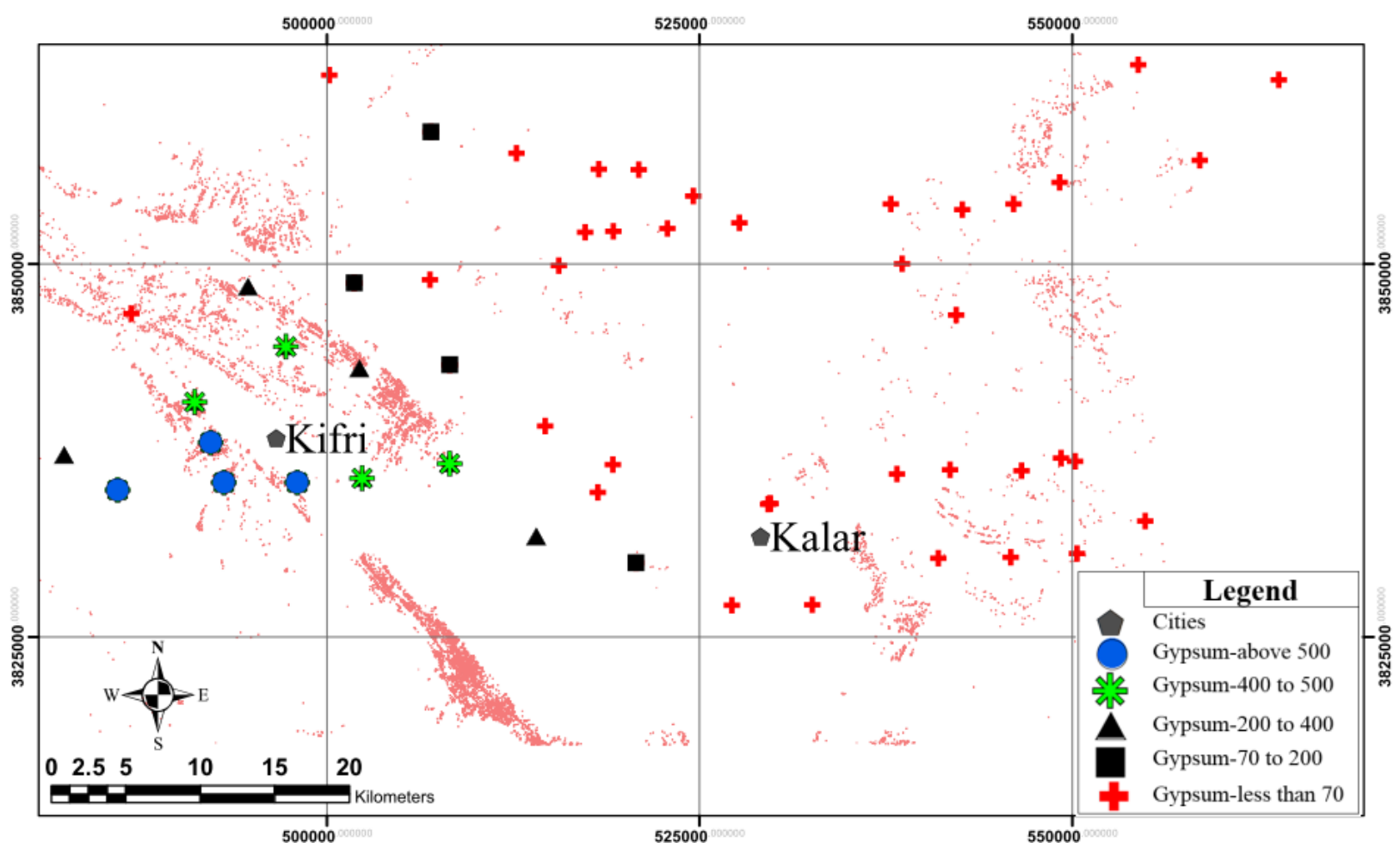

Figure 2: Supervised classification (maximum likehood), preceded by applying PCA on the satellite image. Down-right legend shows the field point and their gypsum level in $(\mathrm{mg})$.

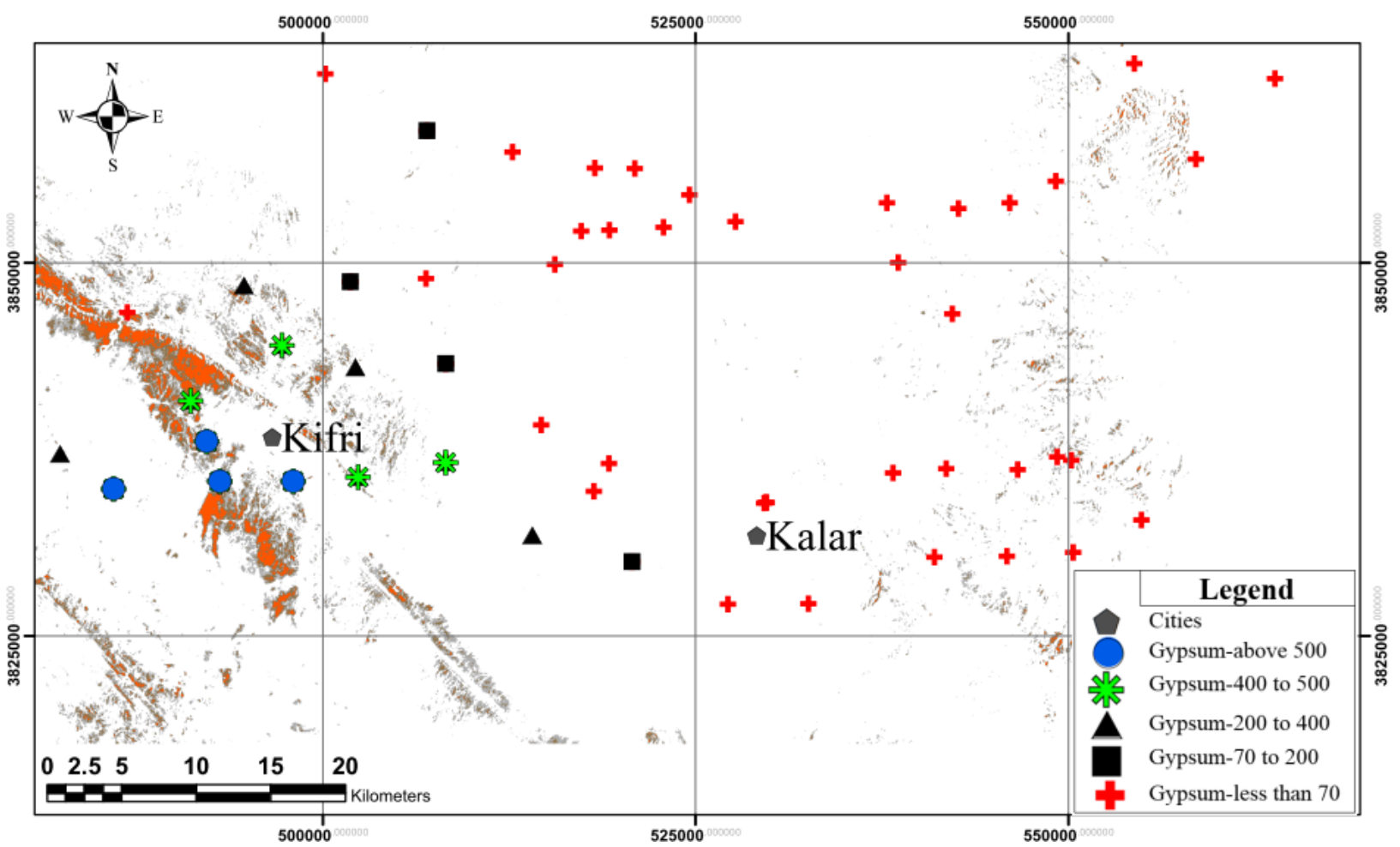

Figure 3: Thermal-based map. Upper-left legend shows the temperature in Kelvin, while down-right legend shows the field point and their gypsum level in (mg). 

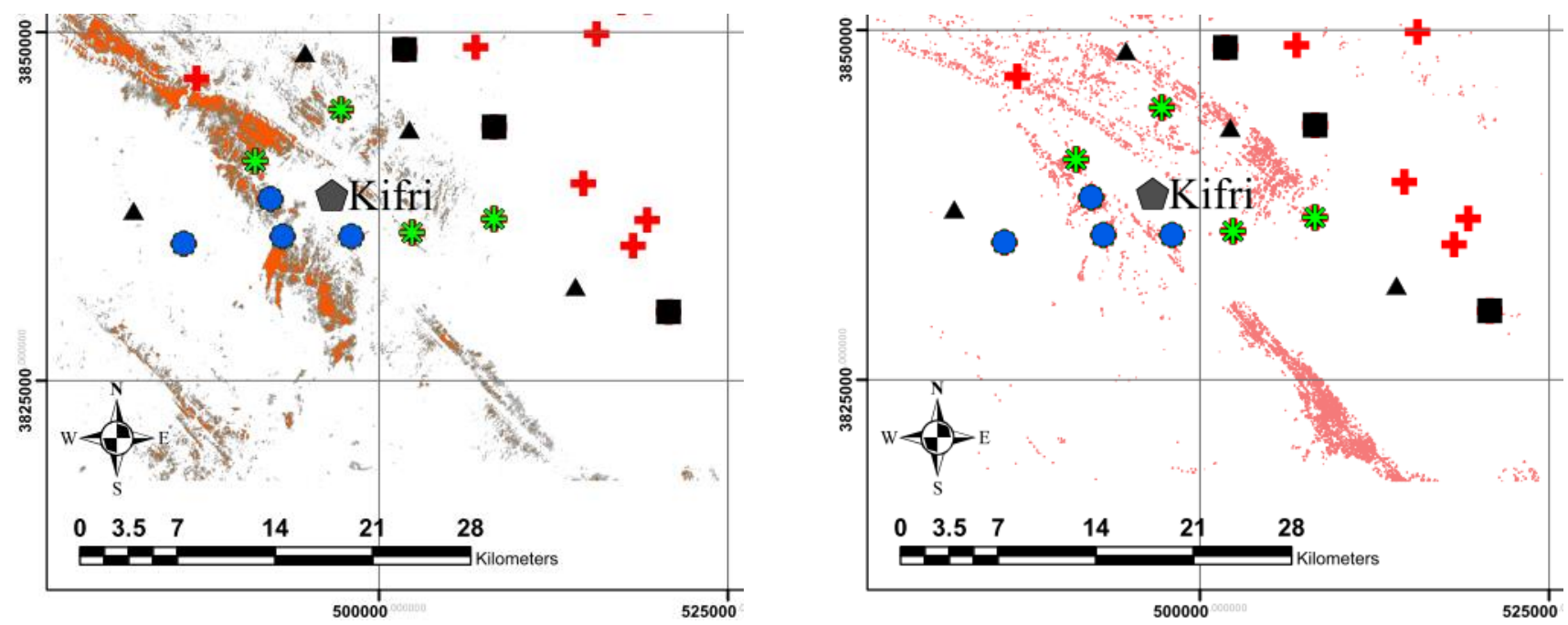

Figure 4: Comparison between two applied methods in terms of precision for prediction high gypsiferous areas. The left is thermal, while the right is supervised non-thermal classified map.

\section{RECOMMENDATIONS}

It's suggested to use different satellite resources with different spatial and spectral resolution (e.g. Hyperion and Spot), to get more precise and reliable outputs. According to the outputs, therefore, it can be implied that remote sensing integrated with field observations, as control points, can be used successfully to find out where, and to what level, may contains gypsum. It should be mentioned that the precision of the estimation is strongly depends on the spectral and spatial resolution of the image and field observations, as well as the method and necessary corrections which may be needed to be applied on the satellite image.

\section{REFERENCES}

[1] A. S. Muhaimed, and R. A. Mahmood, "Genesis and development of some Gypsiferous soils in Iraq," ALTAQANI Journal of Foundation of technical education. ISSN. 1818653x. Vol. 24. Issue. 5. PP. 8899, 2011.

[2] A. A. Jafarzadeh, and J. A Zinck, "Worldwide distribution and sustainable management of soil with gypsum," ISD Ana sayfasi, 2000.

[3] M. A. Al-Dabbas, T. Schanz, and M. J. Yassen, "Comparasion of gypsiferous soils in Samarra ang Karbala areas, Iraq," Iraqi Bulletin of Geology and Mining. No. 2. Vol. 6. PP. 115-126, 2010.

[4] A. F. Barazanji, "Gypsiferous Soils of Iraq," D.Sc. Thesis, State University of Ghent, Belgium. PP. 1 - 2, 1973.

[5] British Standards Institution (B.S.I.), Methods of Testing Soils for Civ. Eng. Purposes. B.S. 1377, 1975.

[6] FAO - UNESCO., "Soil Map of the World," Vol.1. Legend - UNESCO, Paris, 1975.

[7] V. P. Petrukhin, and G. B. Boldyrev, "Investigation of the deformability of gypsified soil by a static load, translated from Osnovaniya," MSFE (English). No.3. Vol. 15. PP. 178 - 182, 1978.
[8] Soil and Rock Building Stones, American Society for Testing Materials (ASTM), Sec. Vol. 4, PP.4-8, 1986.

[9] M. J. Yassin, "Some geotechnical properties of soils in the Anah area, Western Desert, Iraq," GEOSURV, int. Rep. No. 1556, 1988.

[10] M. J. Yassin, "Study of geotechnical, mineralogical, and geochemical properties of gypsiferous soils for selected samples from Samarra, Falluja, Najaf and Karbala areas, Central Iraq," Unpub. Ph.D. Thesis. University of Baghdad, 2006.

[11] S. N. Seleam, "Geotechnical Characteristics of Gypseous Sandy Soil Including the Effect of Contamination with Some Oil Products," Unpub. M.Sc. Thesis, University of Technology. Baghdad, 1988.

[12] R. Maharaj, "Engineering geological mapping of tropical soils for Land use planning and geotechnical purpose," Jour. Eng. Geo., Vol.40, No.314, 243pp, 1995.

[13] I. H. Nashat, "Engineering Characteristics of some Gypseous Soil in Iraq," Unpub. Ph.D. Thesis. University of Baghdad, 1990.

[14] H. M. A. Al-Khuzaie, "The Effect of Leaching on the Engineering Properties of Al-Jazirah Soil," Unpub. M.Sc. Thesis, Mosul University, 1985.

[15] N. M. Al-Mohammadi, and I. H, Nasha'at. "Compressibility and collapse of gypseous soils," Proc. of 8th Asian Reg. Conf., Tokyo, Japan. PP On SMFE, Vol. 1, PP. 20 - 24, 1987.

[16] F. Al-Qaissy, "Effect of Gypsum Content and its Migration on Compressibility and Shear Strength of the Soil," Unpub. M.Sc. Thesis. University of Technology. Baghdad, 1987.

[17] A. H. Al-Aithawi, "Time Dependent Deformation of a Gypseous Silty Soil," Unpub. M.Sc. Thesis, University of Baghdad, 1990.

[18] W. A. Zakaria, "Permeability of Gypseous soil," Unpub. M.Sc. Thesis, University of Technology, Baghdad, 1995. 
[19] B. S. Al-Busoda, "Studies on the Behavior of Gypseous Soil and its Treatment During Loading," Unpub. M.Sc. Thesis, University of Baghdad, 1999.

[20] M. Al-Beiruty, "Collapse Potential Determination of Gypseous Soils," Unpub. M.Sc. Thesis, University of Technology, Baghdad, 2003.

[21] M. A. Mulders, and G. F Epema, "The Thematic Mapper. A new tool for soil mapping in arid areas," ITC Journal. No. 1. PP. 24-29, 1998.

[22] J. E. Chapman, D. A Rothery, P. W. Francis and A. Pontual, "Remote sensing of evaporite mineral zonation in salt flats (salars)," Internal Journal of Remote Sensing. Vol. 10. Issue. 1. PP. 245-255, 1989.

[23] R. G. Bryant, "Validated linear mixture modeling of Landsat TM data for mapping evaporate minerals on a playa surface. methods and application," J. Remote Sensing No. 17. Vol. 2. PP. 315-330, 1996.

[24] P. Giriprakash, S. Natarajan, S. Ramu and V.E. Nethaji Mariapen, "Evaluation of suitability of forage crops and amendments for the rehabilitation of Gypsum mined soils," Tropical Agriculture Research .Vol. 8. P. 114-123, 1996.

[25] J. K. Crowley, and S. J. Hook,"Mapping playa evaporate minerals and associated sediments in Death Valley, California, with multispectral thermal infrared images. Journal of Geophysics research," Volume 101. Issue B1. PP. 643-660, 1996.

[26] S. N. Aeez, "Identification of Soil Map Units and Vegetation Indices Using Geoinformatics Techniques for Garmyan, Kurdistan Region, Iraq," Ph. D. Dissertation, College of Agriculture. Sulaimani University, Iraq, 2013.

[27] P. Buringh, "Soil and soil condition in Iraq,"' Ministry of Agriculture. Baghdad, Iraq, 1960.

[28] H. V. Dunnington, "Generation, migration, accumulation and dissipation of oil in northern of Iraq," In. L.G. Weeks (ed), Habitat of Oil, Amer. Assoc. Petroleum Geologist. PP. 1194-1251, 1958.

[29] N. S. Kharrufa, "Simplified equation for evaportranspiration in arid regions," Beitrage Zure Hydrology. No. 5. PP. 39-47, 1985.

[30] F. H. Al-Taie, C. Sycand, and G. Stoops, "Soil groups of Iraq, their classification and characteristicspedologie", No. 19. PP.65-148, 1969.

[31] J. K. Kassim, K. Z. Al-Janabi, and M. I. Karim, "Soil temperature regimes in Iraq. II-Relationships between soil temperature and latitude, longitude and ElevationJ," Agri. Water reso. Res. No. 1. Vol. 8. PP. 111-121, 1989.

[32] FAO (Food and Agriculture Organization) of U.N. "Agricultural pest and their control principles," Offset press, Erbil-Iraq, 2000.
[33] F. H. Al-Taie, "The soils of Iraq", Ph.D. thesis, State Univ. of Ghant, Belgium, 1968.

[34] S. M. Ahmad, "Natural map of Iraqi Kurdistan region," 2005.

[36] C.A. Bower, and R. B. Huss, "Rapid conductimetric method for estimating gypsum in soils," Soil Sci. No. 66. PP. 199-204, 1948.

[35] S. N. Goward, J. G. Masek, D. L. Williams, J. R. Irons, and R. J. Thompson, "The Landsat 7 mission," Terrestrial research and applications for the 21st century .Vol. 78. Issues 1-2. PP. 3-12, 2001.

[37] P. R. Hesse, "Particle size distribution in gypsic soils," Plant and Soil. Vol. 44. PP. 241-247, 1976.

[38] Procedures for soils, analysis ISRIC (International Soil Reference and Information Centre). International Soil Reference and Information Centre. Wageningen, 1987.

[39] J. S. Deng, K. Wang, Y. H. Deng and G. J. Qi., "PCA based land use change detection and analysis using multitemporal and multisensor satellite data," International Journal of Remote Sensing. Vol. 29. Issue. 16. PP. 4823-4838, 2008.

[40] R. Goossens, and E. V. Ranst, "The use of remote sensing to map gypsiferous soils in the Ismailia Province," Egypt. Vol. 78. Issue 1-2. PP. 47-56, 1998.

[41] M. S. Jamalabad, and A. A. Abkar, "Forest canopy density monitoring using satellite images," In XXth ISPRS Congress. Istanbul. Turkey. International Society for Photogrammetry and Remote Sensing. PP. 244-249, 2004.

[42] G. D. Smith, F. Newhall, L. H. Robinson, and D. Swanson, "Soil temperature regimes. their characteristics and predictability. US Soil Conservation," Serv. Rept. SCS-TP-144. P: 13, Washington. DC, 1964.

[43] A. H. F. Amry, "The impact of gypsiferous and calcareous soils on decomposition of different organic materials," Diyala Journal of Agricultural Sciences, No. 5. Vol. 2. PP. 133-143, 2013.

[44] A. H. F. Amry, "Effect of gypsum soil content on the decomposition of different organic matter and formation of humic acid and its effect on the state and behavior of potassium," M.Sc. Thesis, College of Agriculture. University of Tikrit, 2011

[45] B. Sh. Al-Obeidi, "Different sources of membership and relationship with the faculty," M.Sc. Thesis, College of Agriculture. University of Baghdad, 2001.

[46] K. H. Tan, "Principle of soil chemistry," Department of crop and soil science, University of Georgia. MARCEL DEKKER. INC, 2005. 